\title{
Intestinal parasite infections and associated risk factors in communities exposed to wastewater in urban and peri-urban transition zones in Hanoi, Vietnam
}

\author{
Samuel Fuhrimann ${ }^{1,2^{*}}$, Mirko S. Winkler ${ }^{1,2}$, Phuc Pham-Duc ${ }^{3}$, Dung Do-Trung ${ }^{4}$, Christian Schindler ${ }^{1,2}$,
} Jürg Utzinger ${ }^{1,2}$ and Guéladio Cissé $e^{1,2}$

\begin{abstract}
Background: Infections with intestinal parasites (helminths and intestinal protozoa) are endemic in Southeast Asia and inappropriate management and reuse of wastewater might exacerbate the risk of human infections. In rapidly growing urban settings, little is known about the extent of intestinal parasite infections. We assessed the pointprevalence and risk factors of intestinal parasite infections in population groups differently exposed to wastewater in urban and peri-urban transition zones in Hanoi, the capital of Vietnam.

Methods: A cross-sectional survey was carried out between April and June 2014 in people aged $\geq 18$ years at risk of wastewater exposure from To Lich River: workers maintaining wastewater treatment facilities; urban farmers reusing wastewater; and urban dwellers at risk of flooding events. For comparison, two peri-urban population groups living in close proximity to the Red River were chosen: farmers using river water for irrigation purposes; and people living in the same communities. A single stool sample was subjected to Kato-Katz and formalin-ether concentration methods for the diagnosis of helminth and intestinal protozoa infections. A questionnaire was administered to determine risk factors and self-reported signs and symptoms.

Results: A total of 681 individuals had complete data records. Highest point-prevalence rates of intestinal parasite infections were observed for peri-urban farmers (30\%). Hookworm and Trichuris trichiura were the predominant helminth species ( $25 \%$ and $5 \%$, respectively). Peri-urban farmers were at higher odds of infection with intestinal parasites than any other groups (adjusted odds ratio 5.8, $95 \%$ confidence interval 2.5 to 13.7). Lack of access to improved sanitation and not receiving deworming within the past 12 months were associated with higher infection risk, while higher educational attainment and socioeconomic status were negatively associated with intestinal parasite infections.

Conclusions: Our results suggest that exposure to wastewater was not directly associated with infection with helminths and intestinal protozoa in different population groups in Hanoi. These findings might be explained by a high level of awareness of health risks and access to safe sanitary infrastructure in urban areas. The high prevalence rates observed in peri-urban farmers call for specific interventions targeting this population group.
\end{abstract}

Keywords: Helminth, Intestinal protozoa, Peri-urban farming, Urban farming, Vietnam, Wastewater

\footnotetext{
* Correspondence: samuel.fuhrimann@unibas.ch

${ }^{1}$ Swiss Tropical and Public Health Institute, Basel, Switzerland

2University of Basel, Basel, Switzerland

Full list of author information is available at the end of the article
} 


\section{Background}

In Southeast Asia, infections with intestinal parasites (e.g. helminths and intestinal protozoa) cause a considerable public health burden [1, 2]. Despite efforts to control morbidity and interrupt transmission, infection with soiltransmitted helminths (Ascaris lumbricoides, hookworm, Strongyloides stercoralis and Trichuris trichiura) are common and show geographic, demographic, socioeconomic and cultural differences within and across countries of Cambodia, Lao People's Democratic Republic (PDR) and Vietnam [3-5]. In urban areas, socioeconomic development, including improvements in sanitation and water infrastructures are thought to be associated with a decline in the prevalence and intensity of intestinal parasites over the past decades [6-8]. However, in rural areas and deprived urban and peri-urban settings, access to clean water and improved sanitation remains insufficient and is an important risk factor for infections with helminth and intestinal protozoa [9, 10]. Additionally, reuse of wastewater and faeces in agriculture and aquaculture might contribute to the transmission of intestinal parasites $[2,11]$.

Hanoi, the capital of Vietnam, has undergone considerable economic growth since the end of the Vietnam War in 1975, resulting in a change in lifestyles and increased living standards. Moreover, population growth and ruralurban migration led to an expansion of the city boundaries [12]. Due to rapid urbanization, improved access to health care and awareness campaigns are available (i.e. yearly deworming of school-aged children and hygiene campaigns such as "eating cooked food and drinking boiled water"), which decreased prevalence of intestinal parasitic infections [13]. However, increasing volumes of domestic waste, mixed with chemical and microbial pollutants, have increased the heterogeneity in exposure to such pollutants and pathogens [14, 15]. Especially for urban and peri-urban transition zones around Hanoi, it is crucial to ensure access to basic water and sanitation infrastructures. Moreover, guidance on safe management and reuse of wastewater is needed $[6,7$, 16]. It is conceivable that increasing volumes of wastewater might exacerbate the spread of intestinal parasites, enteric bacteria and viruses [16, 17]. Moreover, past extreme weather events, such as heavy rains, jeopardized the proper functionality of Hanoi's sanitation systems, with likely adverse health outcomes [18].

In urban and peri-urban areas of Hanoi, an estimated 650,000 farmers reuse wastewater in agriculture and aquaculture to supply the 6.7 million people living in the city with fresh vegetables and fish [19]. Use of wastewater comes at low cost for water and nutrients, and hence provides an important livelihood opportunity for farming communities [20]. Of note, lack of sanitation facilities and use of human excreta in such communities were shown to be a major risk factor for intestinal parasite infections. Moreover, diarrhoeal and skin diseases have been associated to occupational contact with wastewater [13, 21-24]. In more rural communities, the occupational exposure to Hanoi's reused wastewater has also been associated with $A$. lumbricoides and $T$. trichiura infections [2]. Thus, it is commonly observed in urban communities that the prevalence rates of intestinal parasitic infections are lower than in peri-urban and rural areas [1]. Over the past decade, a number of studies indicated levels of microbial and chemical pollution above national and international safety standards in the environment [15, 25-28]. Thus, pollution reduction may not be sufficient to allow for safe reuse of wastewater for agriculture and aquaculture [29].

As the city of Hanoi expanded rapidly, with annual population growth rates of up to $3.5 \%$, timely data on prevalence and risk factors of infection with helminths and intestinal protozoa are needed to understand the effect of urbanization in urban and peri-urban transition zones [12]. Surveys investigating prevalence rates and risk factors for parasitic diseases, diarrhoea, skin and eye infections in the urban and peri-urban environment around Hanoi are dating back to 2005 [13, 21-24]. Such data will help to effectively plan public health interventions and justify investments in sanitary infrastructures [16, 30]. The objective of the present study was to assess the prevalence rates and risks factors for intestinal parasite infections in different population groups exposed to wastewater reuse activities in Hanoi.

\section{Methods}

\section{Study design and participants}

A cross-sectional survey was conducted between April and June 2014. The study was undertaken in the southern part of Hanoi, along To Lich River (main open storm water and drainage channel of the city) and Red River (natural river stemming from the People's Republic of China that is discharged in the Gulf of Tonkin). These rivers receive most of the city's wastewater, managed by Hanoi Sewerage and Drainage Company (HSDC). However, water quality differs considerably: while water of the To Lich River is not allowing for the safe reuse of wastewater in agriculture and aquaculture according the World Health Organization (WHO) guidelines, the Red River water quality is within tolerable limits colony forming unit (CFU) total coliforms and Escherichia coli $\left(4.2 \times 10^{6} \mathrm{CFU} / 100 \mathrm{ml}\right.$ and $1.7 \times$ $10^{4} \mathrm{CFU} / 100 \mathrm{ml}$, respectively). Helminth eggs were only found in To Lich River $(0.1 \mathrm{egg} / \mathrm{l})$, which however is still within the WHO tolerable concentration for safe reuse [16, 29]. Particular emphasis was placed to the wastewater reuse in agriculture and aquaculture in urban and peri-urban transition zones of the districts Hoang Mai and Thanh Tri (geographical coordinates: $21^{\circ} 01^{\prime} 42.5^{\prime \prime} \mathrm{N}, \quad 105^{\circ} 51^{\prime} 15.0^{\prime \prime} \mathrm{E}$ ) 


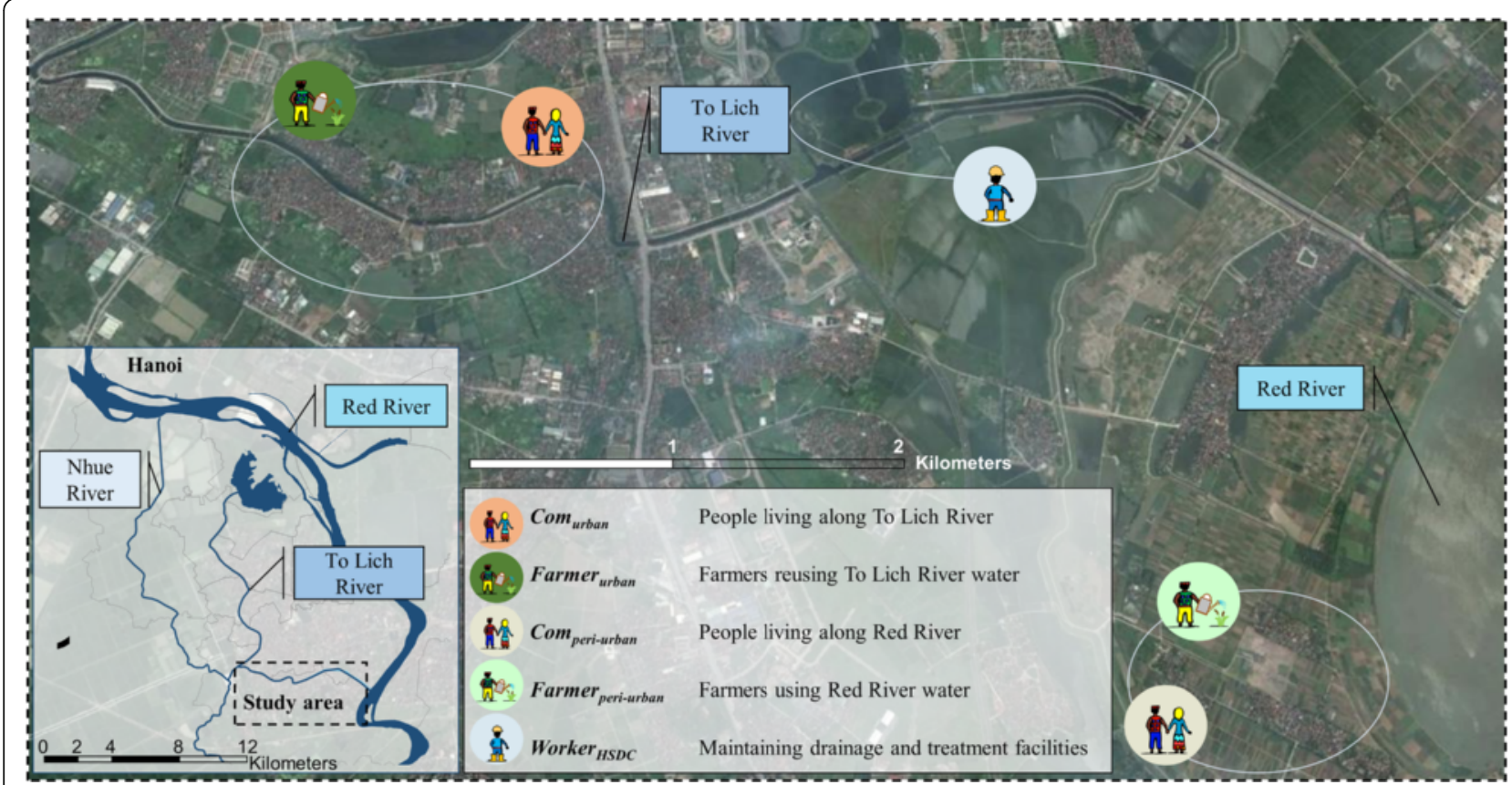

Fig. 1 Map of Hanoi showing the study area and the five exposure groups in the Than Tri district. (Map data @2015 Google)

(Fig. 1). A detailed description of the study system and water quality of the rivers is published elsewhere [29].

The study enrolled adults (aged $\geq 18$ years) living and working in urban or peri-urban areas in the two districts. According to the level of exposure to wastewater, the study participants were stratified into five population groups: three exposed to wastewater from To Lich River (i-iii); and two comparison groups living along Red River without direct exposure to urban wastewater (iv and v):

(i) "Com urban", people living in the urban to peri-urban transition zone of Hanoi, in Bang B village or Tam Hiep commune along To Lich River who are potentially exposed to wastewater while flooding events occur during the rainy season. The communities are located in Hoang Mai and Thanh Tri district, respectively (geographical coordinates: $\left.20^{\circ} 57^{\prime} 17.54^{\prime \prime} \mathrm{N}, 105^{\circ} 49^{\prime} 42.48^{\prime \prime} \mathrm{E}\right)$, and are prone to rapid demographic transition, industrial development and land use change.

(ii) "Farmer urban", urban farmers living in Bang B village or Tam Hiep commune reusing wastewater from To Lich River. A large part of the community members (33\%) are involved in agriculture (e.g. rice, morning glory, neptunia and watercress mainly) or aquaculture activities [31].

(iii) "Worker ${ }_{H S D C}$ ", workers from HSDC maintaining drainage channels and operating the Yen So treatment plants along To Lich River. (iv) "Comperi-urban", people living in Duyen $\mathrm{Ha}$ commune (comparison group). The commune represents a typical peri-urban community along Red River with poor sanitation and drinking water systems. The commune belongs to Thanh Tri district and is located approximately $5 \mathrm{~km}$ from the outskirt of Hanoi (geographical coordinates: $20^{\circ}$ 55'42.37"N, 10552'23.32"E).

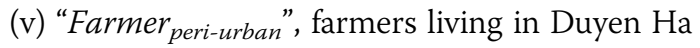
commune using the irrigation water from Red River (comparison group). About $38 \%$ of the people work in agriculture.

Sample size was calculated by aiming at a power of $95 \%$, to ensure that a reduction in effective exposure variance by $35 \%$ following confounder adjustment would still leave $80 \%$ power. Our assumptions were that the prevalence of intestinal parasite infections is at least $20 \%$ in Comperi-urban $_{\text {pan }}$ and the odds ratio (OR) of Farmer urban $_{\text {, }}$ and Worker $_{H S D C}$ to

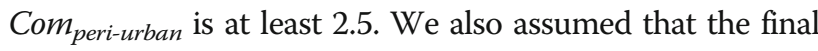
sample size might be reduced by $15 \%$ due to loss to follow-up. Hence, our intended sample size was 1,025 $\left(\right.$ Com $_{\text {urban }}, n=250$; Farmer $_{\text {urban }}, n=250$; Com peri-urban $_{\text {, }} n=$ 175; Farmer peri-urban $_{1} n=175$; and Worker $_{H S D C}, n=150$ ).

The following inclusion and exclusion criteria were applied. First, households were randomly selected from two separate lists (one for farming and one for all nonfarming households in the community) readily available from the communal people committees. All listed households were numbered and the appropriate number 
selected using a random number list from Excel. All individuals in the selected households were invited to participate in the survey. If they were willing to participate, one person per household (household heads or adults living permanently in the household) was selected for a questionnaire interview at a convenient time at the community health station. Participants were provided with a stool container and asked to return a filled container the day of the interview with her or his own morning stool sample. To select members of Worker $_{H S D C}$, the HSDC headquarter mobilized and informed the workers and randomly selected them from the existing staff list. Worker $_{H S D C}$ were then invited to come on a fixed day for the interview along with a fresh morning stool sample to the health station of the HSDC the day after the interview.

\section{Procedures}

We employed a questionnaire to determine exposure pathways to wastewater, potential confounding factors (e.g. demographic and socioeconomic), risk variables (e.g. water, sanitation, hygiene and occupation) and self-reported signs and symptoms. Our questionnaire had previously been validated in a study in Uganda [32]. The questionnaire was translated into Vietnamese, and further adapted to the Hanoi context and pre-tested among five farmers and five community members not otherwise involved in the current study. Research assistants entered data directly into tablet computers (Samsung Galaxy note 10.1 N8010) via a data entry mask using Open Data Kit (http://opendatakit.org).

Participants were invited to provide a fresh morning stool that was subjected to the Kato-Katz technique (duplicate thick smears, using standard $41.7 \mathrm{mg}$ template) [33] and a formalin-ether concentration technique (FECT) [34] for the diagnosis of helminths (A. lumbricoides, hookworm, T. trichiura and other helminths) and intestinal protozoa (Blastocystis hominis, Chilomastix mesnili, Endolimax nana, Entamoeba coli, Entamoeba histolytica/E. dispar, Entamoeba hartmanni, Giardia intestinalis and Iodamoeba bütschlii). Kato-Katz thick smear and FECT readings were doubleentered and cross-checked.

Table 1 Demographic and socioeconomic characteristics of the participants enrolled in the cross-sectional survey, stratified by five exposure groups in the Than Tri district, Hanoi, between April and June 2014

\begin{tabular}{|c|c|c|c|c|c|c|c|c|c|c|}
\hline \multirow{3}{*}{$\begin{array}{l}\text { Demographic and socioeconomic characteristics/ } \\
\text { Exposure groups }^{\mathrm{a}}\end{array}$} & \multirow{2}{*}{\multicolumn{2}{|c|}{$\begin{array}{l}\text { Com }_{\text {peri-urban }} \\
N=101\end{array}$}} & \multirow{2}{*}{\multicolumn{2}{|c|}{$\begin{array}{l}\text { Com urban }_{\text {un }} \\
N=170\end{array}$}} & \multirow{2}{*}{\multicolumn{2}{|c|}{$\begin{array}{l}\text { Farmer }_{\text {peri-urban }} \\
N=129\end{array}$}} & \multirow{2}{*}{\multicolumn{2}{|c|}{$\begin{array}{l}\text { Farmer }_{\text {urban }} \\
N=153\end{array}$}} & \multirow{2}{*}{\multicolumn{2}{|c|}{$\begin{array}{l}\text { Worker }_{H S D C} \\
N=128\end{array}$}} \\
\hline & & & & & & & & & & \\
\hline & $n$ & $\%$ & $n$ & $\%$ & $n$ & $\%$ & $n$ & $\%$ & $n$ & $\%$ \\
\hline \multicolumn{11}{|l|}{ Sex } \\
\hline Female & 85 & 84.2 & 134 & 78.8 & 105 & 81.4 & 132 & 86.3 & 58 & 45.3 \\
\hline Male & 16 & 15.8 & 36 & 21.2 & 24 & 18.6 & 21 & 13.7 & 70 & 54.7 \\
\hline Age categories (years) (mean $\pm S D$ ) & \multicolumn{2}{|c|}{$50.0 \pm 15.6$} & \multicolumn{2}{|c|}{$45.7 \pm 14.5$} & \multicolumn{2}{|c|}{$48.7 \pm 11.1$} & \multicolumn{2}{|c|}{$52.6 \pm 10.6$} & \multicolumn{2}{|c|}{$41.2 \pm 10.7$} \\
\hline \multicolumn{11}{|l|}{ Educational attainment } \\
\hline Never went to school & 3 & 3.0 & 7 & 4.1 & 0 & 0.0 & 5 & 3.3 & 0 & 0.0 \\
\hline Primary school & 13 & 12.9 & 16 & 9.4 & 19 & 14.7 & 42 & 27.5 & 2 & 1.6 \\
\hline Secondary school & 47 & 46.5 & 70 & 41.2 & 76 & 58.9 & 76 & 49.7 & 37 & 28.9 \\
\hline Tertiary school & 15 & 14.9 & 59 & 34.7 & 31 & 24.0 & 27 & 17.6 & 73 & 57.0 \\
\hline University degree & 23 & 22.8 & 18 & 10.6 & 3 & 2.3 & 3 & 2.0 & 16 & 12.5 \\
\hline \multicolumn{11}{|l|}{ Socioeconomic status ${ }^{b}$} \\
\hline Most poor & 28 & 27.7 & 31 & 18.2 & 51 & 39.5 & 33 & 21.6 & 12 & 9.4 \\
\hline Poor & 22 & 21.8 & 49 & 28.8 & 42 & 32.6 & 48 & 31.4 & 17 & 13.3 \\
\hline Less poor & 17 & 16.8 & 41 & 24.1 & 25 & 19.4 & 34 & 22.2 & 56 & 43.8 \\
\hline Least poor & 34 & 33.7 & 49 & 28.8 & 11 & 8.5 & 38 & 24.8 & 43 & 33.6 \\
\hline How many people live in your household (mean \pm SD) & \multicolumn{2}{|c|}{$4.7 \pm 2.0$} & \multicolumn{2}{|c|}{$4.6 \pm 1.7$} & \multicolumn{2}{|c|}{$4.3 \pm 1.9$} & \multicolumn{2}{|c|}{$5.1 \pm 2.6$} & \multicolumn{2}{|c|}{$5.3 \pm 8.5$} \\
\hline Living at the same place (years) (mean \pm SD) & \multicolumn{2}{|c|}{$34.4 \pm 21.3$} & \multicolumn{2}{|c|}{$37.7 \pm 19.8$} & \multicolumn{2}{|c|}{$37.8 \pm 19.5$} & \multicolumn{2}{|c|}{$53.3 \pm 56.3$} & \multicolumn{2}{|c|}{$34.0 \pm 14.5$} \\
\hline
\end{tabular}

${ }^{a}$ Exposure groups: Com peri-urban: people living in the peri-urban commune Duyen $\mathrm{Ha}, 5 \mathrm{~km}$ away from the city along the Red River; Com $_{\text {urban: }}$ people living in the

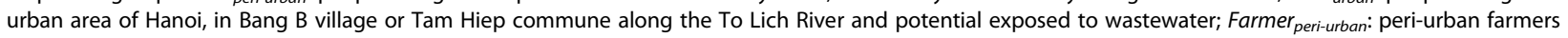
living in Duyen Ha commune using the irrigation water from Red River, wells or local drains, which are not contaminated with the city's wastewater; Farmer urban: urban farmers living in Bang B village or Tam Hiep commune reusing wastewater from To Lich River; and Worker $_{H S D C}$ : workers from Hanoi Sewerage and Drainage Company (HSDC) maintaining drainage channels and operating the Yen So treatment plants

${ }^{b}$ Derived using principal components analysis (PCA) of the following 11 ownership items: radio, TV, mobile phone, fridge, computer, bicycle, motorbike, car, electricity, running water and latrine 


\section{Statistical analysis}

Helminth- and intestinal protozo-specific proportions were compared between the five exposure groups, using Pearson's $X^{2}$ test. Univariate logistic regression was applied to investigate for potential associations between nine dependent variables, i.e. infections with (i) any intestinal parasite; (ii) soil-transmitted helminth; (iii) intestinal protozo; (iv) A. lumbricoides; (v) hookworm; (vi) $T$. trichiura; (vii) 14-day diarrhoea prevalence; (viii) skin problems; and (ix) eye problems), and 20 independent variables (e.g. exposure groups, sex and age). A measure of socioeconomic status was derived, based on an asset index using principal components analysis (PCA), with participants grouped into four categories, as summarised in Table 1 (most poor, poor, less poor and least poor) [35]. Our multivariate core model included the categorical exposure variables sex, age, educational attainment and socioeconomic status [9, 36]. We then added risk factors that had a $P$-value lower than 0.2 (using likelihood ratio test) in the univariate analyses. Of note, a univariate or multivariate analysis was only conducted if the number of respective cases was above 50 or 70 , respectively.

ORs were reported to compare risks. Differences and associations were considered as statistically significant if their $P$-values were below 0.05 and as indicating a trend if $P$-values were between 0.05 and 0.1 . Statistical analyses were done using STATA version 12.0 (Stata Corporation; College Station, USA).

\section{Results}

Among 1,025 people invited, 813 fulfilled our inclusion criteria, provided written informed consent and completed the questionnaire interview (Fig. 2). Stool samples were provided by 718 individuals that were subjected to KatoKatz thick smear examination. Due to insufficient volumes of stool provided, only 681 of the samples were subjected to FECT. These 681 individuals were considered as the final study cohort, composed of 170 Com $_{\text {urban }}$, 153 Farmer urban, 129, Farmer peri-urban, 128 Worker $_{H S D C}$ and 101 Com $_{\text {peri-urban }}$.

Table 1 summarises the demographic (sex, age, educational attainment, people per household, living duration at the same place) and socioeconomic characteristics, stratified by the five population groups. In brief, females accounted for $79 \%$ and more in all exposure groups, expect for Worker $_{H S D C}(45 \%)$. Most of the participants ( $>60 \%$ ) were aged above 40 years and attended in minimum secondary school. Socioeconomic status was highest in Worker $_{H S D C}$ and Com peri-urban with $34 \%$ classified as "least poor" in both groups. The lowest socioeconomic status was observed in Farmer peri-urban $_{\text {with }} 40$ \% classified as "most poor". On average, between 4.3 and 5.3 people live in a household. Two-thirds of the participants $(65 \%)$ reported that they lived in the study area for at least ten years.

Risk factors for intestinal parasite infections, such as perceived exposure to wastewater, access to sanitation, drinking water and bath water and deworming practise

\begin{tabular}{|c|c|c|c|c|c|}
\hline & $\begin{array}{c}\text { Com }_{\text {peri-urban }} \\
\text { People living in } \\
\text { Duyen Ha } \\
\text { commune along } \\
\text { Red River }\end{array}$ & $\begin{array}{c}\text { Com }_{\text {urban }} \\
\text { People living in } \\
\text { proximity to } \\
\text { To Lich River }\end{array}$ & $\begin{array}{c}\text { Farmer }_{\text {peri-urban }} \\
\text { Farmers using } \\
\text { water from Red } \\
\text { River, wells, or } \\
\text { local drains }\end{array}$ & $\begin{array}{c}\text { Farmer }_{\text {urban }} \\
\text { Farmers reusing } \\
\text { wastewater from } \\
\text { To Lich River }\end{array}$ & $\begin{array}{c}\text { Worker }_{\text {HSDC }} \\
\text { Maintain } \\
\text { wastewater } \\
\text { drainage and } \\
\text { treatment facilities }\end{array}$ \\
\hline $\begin{array}{l}\text { Total population } \\
\text { estimate }\end{array}$ & $\begin{array}{l}\text { Duyen } \mathrm{Ha} \\
\text { commune } \\
\mathrm{n}=1,509\end{array}$ & $\begin{array}{c}\text { Bang B village } \\
\text { and Tam Hiep } \\
\text { commune } \\
\mathrm{n}=15,900\end{array}$ & $\begin{array}{c}\text { Duyen } \mathrm{Ha} \\
\text { commune } \\
\mathrm{n}=580\end{array}$ & $\begin{array}{l}\text { Bang B village } \\
\text { and Tam Hiep } \\
\text { commune } \\
n=5,300\end{array}$ & $\begin{array}{l}\text { HSDC } \\
\mathrm{n}=800\end{array}$ \\
\hline $\begin{array}{l}\text { Invited to participate } \\
(\mathrm{n}=1,025)\end{array}$ & $\mathrm{n}=175$ & $\mathrm{n}=250$ & $\mathrm{n}=175$ & $\mathrm{n}=250$ & $\mathrm{n}=150$ \\
\hline $\begin{array}{l}\text { Informed consent and } \\
\text { questionnaire }(n=813)\end{array}$ & $\mathrm{n}=116$ & $\mathrm{n}=\mathbf{2 0 9}$ & $\mathrm{n}=148$ & $\mathrm{n}=188$ & $\mathrm{n}=150$ \\
\hline $\begin{array}{l}\text { Kato-Katz thick-smear } \\
\text { results }(\mathrm{n}=718)\end{array}$ & 105 & & 136 & $=157$ & $\mathrm{n}=137$ \\
\hline $\begin{array}{l}\text { FECT results } \\
\text { Final study cohort } \\
(\mathrm{n}=681)\end{array}$ & $\mathrm{n}=101$ & $\mathrm{n}=170$ & $\mathrm{n}=129$ & $\mathrm{n}=153$ & $\mathrm{n}=128$ \\
\hline
\end{tabular}

Fig. 2 Flow chart indicating the enrolment of study participants and compliance, stratified into exposure groups in the cross-sectional survey in the Than Tri district, Hanoi, between April and June 2014 
Table 2 Water, sanitation and hygiene (WASH) specific risk factors of the participants enrolled in a cross-sectional survey, stratified by the five exposure groups in the Than Tri district, Hanoi, between April and June 2014

\begin{tabular}{|c|c|c|c|c|c|c|c|c|c|c|}
\hline \multirow{3}{*}{$\begin{array}{l}\text { Risk factors related to water, sanitation } \\
\text { and hygiene/ Exposure groups }{ }^{\mathrm{a}}\end{array}$} & \multirow{2}{*}{\multicolumn{2}{|c|}{$\begin{array}{l}\text { Com }_{\text {peri-urban }} \\
N=101\end{array}$}} & \multirow{2}{*}{\multicolumn{2}{|c|}{$\frac{\text { Com }_{\text {urban }}}{N=170}$}} & \multirow{2}{*}{\multicolumn{2}{|c|}{$\begin{array}{l}\text { Farmer }_{\text {peri-urban }} \\
N=129\end{array}$}} & \multirow{2}{*}{\multicolumn{2}{|c|}{$\frac{\text { Farmer }_{\text {urban }}}{N=153}$}} & \multirow{2}{*}{\multicolumn{2}{|c|}{$\frac{\text { Worker }_{H S D C}}{N=128}$}} \\
\hline & & & & & & & & & & \\
\hline & $n$ & $\%$ & $n$ & $\%$ & $n$ & $\%$ & $n$ & $\%$ & $n$ & $\%$ \\
\hline \multicolumn{11}{|l|}{ Wastewater is ... } \\
\hline polluted water & 87 & 86.1 & 162 & 95.3 & 111 & 86.0 & 143 & 93.5 & 126 & 98.4 \\
\hline causing health issues & 83 & 82.2 & 149 & 87.6 & 96 & 74.4 & 141 & 92.2 & 126 & 98.4 \\
\hline causing environmental issues & 83 & 82.2 & 149 & 87.6 & 93 & 72.1 & 135 & 88.2 & 127 & 99.2 \\
\hline \multicolumn{11}{|c|}{ Exposure to wastewater (water from rivers or lakes around Hanoi) while ... } \\
\hline flooding of living area & 0 & 0.0 & 5 & 2.9 & 3 & 2.3 & 2 & 1.3 & 17 & 13.3 \\
\hline flooding of working area & 1 & 1.0 & 9 & 5.3 & 21 & 16.3 & 59 & 38.6 & 53 & 41.4 \\
\hline washing clothes & 0 & 0.0 & 0 & 0.0 & 0 & 0.0 & 1 & 0.7 & 2 & 1.6 \\
\hline cleaning of a fish pond & 0 & 0.0 & 1 & 0.6 & 0 & 0.0 & 5 & 3.3 & 15 & 11.7 \\
\hline fishing & 3 & 3.0 & 7 & 4.1 & 3 & 2.3 & 6 & 3.9 & 13 & 10.2 \\
\hline swimming & 1 & 1.0 & 3 & 1.8 & 2 & 1.6 & 0 & 0.0 & 6 & 4.7 \\
\hline \multicolumn{11}{|l|}{ Toilet facility at household } \\
\hline Flush toilet & 94 & 93.1 & 167 & 98.2 & 108 & 83.7 & 147 & 96.1 & 127 & 99.2 \\
\hline Pit latrine & 6 & 5.9 & 6 & 3.5 & 2 & 1.6 & 6 & 3.9 & 0 & 0.0 \\
\hline No facility (defecation in the open) & 1 & 1.0 & 1 & 0.6 & 19 & 14.7 & 1 & 0.7 & 1 & 0.8 \\
\hline \multicolumn{11}{|l|}{ Toilet facility at work } \\
\hline Flush toilet & 91 & 90.1 & 150 & 88.2 & 61 & 47.3 & 47 & 30.7 & 39 & 30.5 \\
\hline Pit latrine & 6 & 5.9 & 14 & 8.3 & 4 & 3.1 & 4 & 2.6 & 68 & 53.1 \\
\hline No facility (defecation in the open) & 4 & 4.0 & 6 & 3.5 & 64 & 49.6 & 102 & 66.7 & 21 & 16.4 \\
\hline Household with tap water & 82 & 81.2 & 164 & 96.5 & 102 & 79.1 & 148 & 96.7 & 126 & 98.4 \\
\hline \multicolumn{11}{|c|}{ Source of drinking water (multiple answers possible) } \\
\hline Bottled water & 40 & 39.6 & 65 & 38.2 & 36 & 27.9 & 41 & 26.8 & 61 & 47.7 \\
\hline Tap water & 60 & 59.4 & 149 & 87.6 & 73 & 56.6 & 136 & 88.9 & 113 & 88.3 \\
\hline Rain water & 14 & 13.9 & 5 & 2.9 & 18 & 14.0 & 9 & 5.9 & 7 & 5.5 \\
\hline Bore hole water & 31 & 30.7 & 7 & 4.1 & 43 & 33.3 & 4 & 2.6 & 1 & 0.8 \\
\hline \multicolumn{11}{|c|}{ Source of bathing water (multiple answers possible) } \\
\hline Tap water & 73 & 72.3 & 150 & 88.2 & 55 & 42.6 & 70 & 45.8 & 123 & 96.1 \\
\hline Rain water & 6 & 5.9 & 2 & 1.2 & 11 & 8.5 & 18 & 11.8 & 8 & 6.3 \\
\hline Bore hole water & 42 & 41.6 & 16 & 9.4 & 76 & 58.9 & 9 & 5.9 & 12 & 9.4 \\
\hline Well water & 2 & 2.0 & 0 & 0.0 & 4 & 3.1 & 0 & 0.0 & 2 & 1.6 \\
\hline Water from lakes or rivers & 0 & 0.0 & 1 & 0.6 & 5 & 3.9 & 48 & 31.4 & 19 & 14.8 \\
\hline \multicolumn{11}{|c|}{ Preventive chemotherapy received in the past } \\
\hline$<6$ months & 13 & 12.9 & 15 & 8.8 & 15 & 11.6 & 11 & 7.2 & 15 & 11.7 \\
\hline 6 to $<12$ months & 9 & 14.1 & 24 & 14,1 & 12 & 9.3 & 12 & 7.8 & 20 & 15.6 \\
\hline$>12$ months & 75 & 71.2 & 121 & 71.2 & 96 & 74.4 & 114 & 74.5 & 87 & 68.0 \\
\hline Never took deworming & 4 & 4.0 & 10 & 5.9 & 6 & 5.7 & 16 & 10.5 & 6 & 4.7 \\
\hline
\end{tabular}

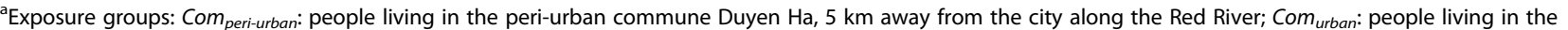
urban area of Hanoi, in Bang B village or Tam Hiep commune along the To Lich River and potential exposed to wastewater; Farmer peri-urban: peri-urban farmers living in Duyen Ha commune using the irrigation water from Red River, wells or local drains, which are not contaminated with the city's wastewater; Farmer urban: urban farmers living in Bang B village or Tam Hiep commune reusing wastewater from To Lich River; and Worker $_{H S D C}$ : workers from Hanoi Sewerage and Drainage Company (HSDC) maintaining drainage channels and operating the Yen So treatment plants 
are shown in Table 2. Almost $90 \%$ of the participants exposed to wastewater perceived wastewater as polluted water, which causes ill-health and environmental risks $\left(\right.$ Com $_{\text {urban }}$, Farmer urban $_{\text {and }}$ arker WSDC $_{H S \text {, while }} 26$ to $28 \%$ Farmer $_{\text {peri-urban }}$ perceived no health and environmental risks due to wastewater. Past flooding of the working area was most frequently reported among Farmer urban $_{\text {(39 \%) and Worker }}$ HSDC (41 \%). Overall, $96 \%$ of participants reported to have a toilet at home, whereas $15 \%$ of the Farmer peri-urban had no accesses to sanitation and thus perform open defecation. Selfreported deworming drugs within the past six months ranged between $7 \%$ (Farmer $\left._{u r b a n}\right)$ and $13 \%\left(\right.$ Com $_{\text {peri- }}$ urban).

Table 3 shows occupational conditions (employment status, working hours, etc.) and protective factors (personal protective equipment) for Farmer peri-urban, Farmer ${ }_{u r-}$ ban and Worker $_{H S D C}$. While all Worker ${ }_{H S D C}$ reported to be officially contracted, $90 \%$ and $91 \%$ of the Farmer $_{\text {peri-urban }}$ and Farmer urban lacked an official employment status, respectively. More than $90 \%$ of all Worker $_{H S D C}$ used different personal equipment (e.g. gloves, boots, uniform) for self-protection against wastewater exposure, while approximately $80 \%$ farmers owned boots and gloves.

The prevalence of infection with any intestinal parasite among Farmer $r_{\text {peri-urban, }}$ Farmer urban, Com $_{\text {urban }}$, Worker $_{H S D C}$ and Comperi-urban $_{\text {was }} 30 \%, 11 \%, 10 \%, 10 \%$ and $7 \%$, respectively (Table 4 and Fig. 3). Only $1 \%$ of the participants was found with multiple intestinal parasitic infections. The highest prevalence of soil-transmitted helminths was found in Farmer peri-urban $_{\text {(25 }}$ \% for hookworm and $5 \%$ for T. trichiura). Ascaris lumbricoides was only detected in Com $_{\text {urban }}$ and Worker $_{H S D C}$; a prevalence of $2 \%$ and $1 \%$, respectively. Infections with soil-transmitted helminths were of light intensity [37]. The prevalence of intestinal protozoa was low; only nine infections with $B$. coli, E. coli and G. intestinalis were found, resulting to an overall prevalence of $1.2 \%$.

The prevalence of self-reported 14-day diarrhoea was not significantly different between study groups and ranged between $12 \%\left(\right.$ Com $\left._{\text {peri-urban }}\right)$ and $4 \%$ (Farmer urban $)$ (Table 5, Fig. 3). However, self-reported rates of skin and eye problems were significantly different between the five exposure groups. General skin problems ranged between

Table 3 Risk factors related to the occupation of workers and farmers enrolled in the cross-sectional survey in the Than Tri district, Hanoi, between April and June 2014

\begin{tabular}{|c|c|c|c|c|c|c|}
\hline \multirow{3}{*}{$\begin{array}{l}\text { Risk factors related to occupation/ } \\
\text { Exposure groups }^{a}\end{array}$} & \multirow{2}{*}{\multicolumn{2}{|c|}{$\begin{array}{l}\text { Farmer }_{\text {peri-urban }} \\
N=129\end{array}$}} & \multirow{2}{*}{\multicolumn{2}{|c|}{$\begin{array}{l}\text { Farmer urban } \\
N=153\end{array}$}} & \multirow{2}{*}{\multicolumn{2}{|c|}{$\begin{array}{l}\text { Worker }_{H S D C} \\
N=128\end{array}$}} \\
\hline & & & & & & \\
\hline & $\bar{n}$ & $\%$ & $n$ & $\%$ & $\bar{n}$ & $\%$ \\
\hline Employed & 13 & 10.1 & 13 & 8.5 & 128 & 100 \\
\hline Retired & 11 & 8.5 & 16 & 10.5 & 0 & 0 \\
\hline Duration worked in the current job (mean \pm SD) & \multicolumn{2}{|c|}{$30.3 \pm 12.9$} & \multicolumn{2}{|c|}{$36.9 \pm 13.5$} & \multicolumn{2}{|c|}{$15.3 \pm 9.1$} \\
\hline Days worked per week (mean \pm SD) & \multicolumn{2}{|c|}{$6.5 \pm 1.2$} & \multicolumn{2}{|c|}{$5.5 \pm 2.1$} & \multicolumn{2}{|c|}{$6.2 \pm 0.6$} \\
\hline Hours worked per week (mean \pm SD) & \multicolumn{2}{|c|}{$39.8 \pm 17.3$} & \multicolumn{2}{|c|}{$35.9 \pm 23.2$} & \multicolumn{2}{|c|}{$50.0 \pm 4.0$} \\
\hline \multicolumn{7}{|l|}{ Possession of personal protective equipment } \\
\hline Gloves & 106 & 82.2 & 113 & 73.9 & 117 & 91.4 \\
\hline Boots & 107 & 82.9 & 131 & 85.6 & 110 & 85.9 \\
\hline Uniform/cotton overall & 28 & 21.7 & 11 & 7.2 & 120 & 93.8 \\
\hline Rain coat with boots & 29 & 22.5 & 48 & 31.4 & 120 & 93.8 \\
\hline Rain coat without boots & 36 & 27.9 & 58 & 37.9 & 84 & 65.6 \\
\hline Long sleeves & 97 & 75.2 & 137 & 89.5 & 48 & 37.5 \\
\hline Helmet & 3 & 2.3 & 1 & 0.7 & 117 & 91.4 \\
\hline Soft hat (baseball cap) & 24 & 18.6 & 37 & 24.2 & 7 & 5.5 \\
\hline Vietnamese hat & 111 & 86.0 & 141 & 92.2 & 4 & 3.1 \\
\hline Face mask & 110 & 85.3 & 105 & 68.6 & 121 & 94.5 \\
\hline \multicolumn{7}{|l|}{ Application of... } \\
\hline Pesticides & 113 & 87.6 & 117 & 76.5 & \multicolumn{2}{|l|}{$n a^{b}$} \\
\hline Fertilizer & 122 & 94.6 & 146 & 95.4 & \multicolumn{2}{|l|}{ na } \\
\hline
\end{tabular}

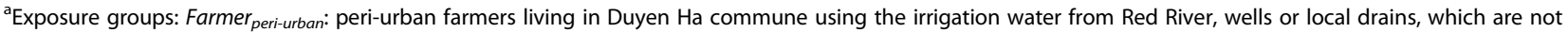
contaminated with the city's wastewater; Farmer urban: urban farmers living in Bang B village or Tam Hiep commune reusing wastewater from To Lich River; and Worker $_{H S D C}$ : workers from Hanoi Sewerage and Drainage Company (HSDC) maintaining drainage channels and operating the Yen So treatment plants

${ }^{\mathrm{b}} \mathrm{na}$, not applicable for sanitation workers 
Table 4 Prevalence and intensity of parasite infections among the participants enrolled in the cross-sectional survey in Hanoi, stratified by five exposure groups in the Than Tri district, Hanoi, between April and June 2014

\begin{tabular}{|c|c|c|c|c|c|c|c|c|c|c|c|}
\hline \multirow{3}{*}{$\begin{array}{l}\text { Prevalence of infection/ } \\
\text { Exposure groups }^{a}\end{array}$} & \multirow{2}{*}{\multicolumn{2}{|c|}{$\frac{\text { Com }_{\text {peri-urban }}}{N=101}$}} & \multirow{2}{*}{\multicolumn{2}{|c|}{$\frac{C_{\text {urban }}}{N=170}$}} & \multirow{2}{*}{\multicolumn{2}{|c|}{$\begin{array}{l}\text { Farmer }_{\text {peri-urban }} \\
N=129\end{array}$}} & \multirow{2}{*}{\multicolumn{2}{|c|}{$\frac{\text { Farmer }_{\text {urban }}}{N=153}$}} & \multirow{2}{*}{\multicolumn{2}{|c|}{$\begin{array}{l}\text { Worker }_{H S D C} \\
N=128\end{array}$}} & \multirow{3}{*}{$\begin{array}{l}\text { Chi-square } \\
\text { test } \\
\text { P-value }\end{array}$} \\
\hline & & & & & & & & & & & \\
\hline & $\bar{n}$ & $\%^{d}$ & $\bar{n}$ & $\%^{\mathrm{c}}$ & $\bar{n}$ & $\%^{c}$ & $\bar{n}$ & $\%^{\mathrm{c}}$ & $\bar{n}$ & $\%^{\mathrm{C}}$ & \\
\hline Intestinal parasite ${ }^{\mathrm{b}}$ & 7 & 6.9 & 17 & 10.0 & 39 & 30.2 & 17 & 11.1 & 13 & 10.2 & $<0.001$ \\
\hline Soil-transmitted helminth ${ }^{c}$ & 6 & 5.9 & 16 & 9.4 & 39 & 30.2 & 15 & 9.8 & 11 & 8.6 & $<0.001$ \\
\hline Intestinal protozoa & 1 & 1.0 & 1 & 0.6 & 2 & 1.6 & 2 & 1.3 & 2 & 1.6 & 0.932 \\
\hline Hookworm & 4 & 4.0 & 6 & 3.5 & 32 & 24.8 & 11 & 7.2 & 5 & 3.9 & $<0.001$ \\
\hline Light infection (1-1,999 epg) & 4 & 4.0 & 6 & 3.5 & 32 & 24.8 & 11 & 7.2 & 4 & 3.1 & $<0.001$ \\
\hline Moderate infection (2,000-3,999 epg) & 0 & 0.0 & 0 & 0.0 & 0 & 0.0 & 0 & 0.0 & 1 & 0.8 & \\
\hline Trichuris trichiura & 2 & 2.0 & 9 & 5.3 & 7 & 5.4 & 4 & 2.6 & 9 & 7.0 & 0.281 \\
\hline Light infection (1-999 EPG) & 2 & 2.0 & 9 & 5.3 & 7 & 5.4 & 4 & 2.6 & 8 & 6.3 & 0.384 \\
\hline Moderate infection (1,000-9,999 epg) & 0 & 0.0 & 0 & 0.0 & 0 & 0 & 0 & 0 & 1 & 0.8 & \\
\hline Ascaris lumbricoides & 0 & 0.0 & 2 & 1.2 & 0 & 0 & 0 & 0 & 2 & 1.6 & 0.252 \\
\hline Light infection (1-4,999 epg) & 0 & 0.0 & 2 & 1.2 & 0 & 0 & 0 & 0 & 1 & 0.8 & $<0.001$ \\
\hline Moderate infection (5,000-49,999 epg) & 0 & 0.0 & 0 & 0.0 & 0 & 0 & 0 & 0 & 0 & 0.0 & $<0.001$ \\
\hline Giardia intestinalis & 0 & 0.0 & 1 & 0.6 & 0 & 0 & 0 & 0 & 1 & 0.8 & 0.612 \\
\hline Entamoeba coli & 0 & 0.0 & 1 & 0.6 & 1 & 0.8 & 2 & 1.3 & 1 & 0.8 & 0.833 \\
\hline Entamoeba histolytica/E. dispar & 0 & 0.0 & 0 & 0.0 & 0 & 0.0 & 0 & 0.0 & 0 & 0.0 & na \\
\hline Balantidium coli & 1 & 1.0 & 0 & 0.0 & 1 & 0.8 & 0 & 0.0 & 0 & 0.0 & 0.403 \\
\hline
\end{tabular}

${ }^{a}$ Exposure groups: Com peri-urban: people living in the peri-urban commune Duyen $\mathrm{Ha}, 5 \mathrm{~km}$ away from the city along the Red River; Com ${ }_{u r b a n}$ : people living in the

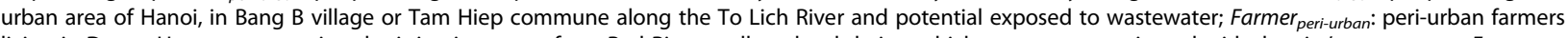
living in Duyen Ha commune using the irrigation water from Red River, wells or local drains, which are not contaminated with the city's wastewater; Farmer urban: urban farmers living in Bang B village or Tam Hiep commune reusing wastewater from To Lich River; and Worker ${ }_{H S D C}$ : workers from Hanoi Sewerage and Drainage Company (HSDC) maintaining drainage channels and operating the Yen So treatment plants

bIntestinal parasitic infection includes: Ascaris lumbricoides, Trichuris trichiura, hookworm and any intestinal protozoa

'Soil-transmitted helminth infection includes: Ascaris lumbricoides, Trichuris trichiura, hookworm

${ }^{\mathrm{d}}$ Prevalence rate is calculated out of the results of the examination of a single stool sample by means of duplicate Kato-Katz and the formalin-ether concentration method, infection intensity by the examination via duplicate Kato-Katz

Abbreviation: epg, eggs per gram; na, not applicable

$27 \%$ (Farmer $\left._{\text {peri-urban }}\right)$ and $12 \%$ (Farmer $\left._{\text {urban }}\right)$. Eye problems were most frequently reported in Farmer urban (38 \%), followed by Worker $_{H S D C}(34 \%)$ and Com urban $(29 \%)$, whereas considerably lower rates of $22 \%$ and $21 \%$ were found in Farmer $r_{\text {peri-urban }}$ and Com peri-urban.

Farmer $_{\text {peri-urban }}$ had the highest adjusted odds of intestinal parasitic infection compared to the other groups (aOR 5.3, 95 \% CI: 2.1-13.7) (Table 6 and Fig. 3). Higher educational attainment and socioeconomic status were negatively associated with parasitic infections, though without statistical significance. Lack of access to toilet at home and not being dewormed for more than 12 months showed an almost significant positive association with intestinal parasitic infection (aOR 3.1, $95 \%$ CI: $0.9-11.0$ and aOR 2.5, 95 \% CI: 0.9-7.0, respectively). By means of univariate regression analysis, higher odds for intestinal parasite infections were observed by at least a factor of 1.7 for all exposure groups when compared to Farmer peri-urban (Fig. 3 and Additional file 1: Tables S1-S6). For hookworm infections, increased risks were observed among Farmer $_{\text {peri-urban }}$ and Farmer urban (OR 8.0, 95 \% CI: 2.7-23.5 and 1.9,
$95 \%$ CI: 2.7-6.1, respectively). For T. trichiura infection, highest risks were observed in Worker $_{H S D C}$ (OR 3.7, 95 \% CI: 0.8-17.7). Risks for eye problems were highest in participants with exposure to wastewater; Farmer urban, Com $_{\text {urban }}$ and Worker $_{H S D C}$ (OR of 2.3, $95 \%$ CI: $1.5-1.9$, respectively). No trend for a difference in risk between the exposure groups was observed for 14-day diarrhoea prevalence.

\section{Discussion}

We report prevalence rates of, and risk factors for, intestinal parasite infections in urban and peri-urban communities that are at different levels of exposure to the wastewater reuse system in Hanoi, Vietnam. The highest prevalence of intestinal parasite infections was observed in peri-urban farmers (30\%), whereas lower prevalences (<11\%) were found in urban farmers reusing wastewater, workers who maintain the wastewater channels and common urban and peri-urban community members. Hookworm was the predominate soil-transmitted helminth with an overall prevalence of $25 \%$ in peri-urban farmers. Peri-urban farmers were at a significantly higher 


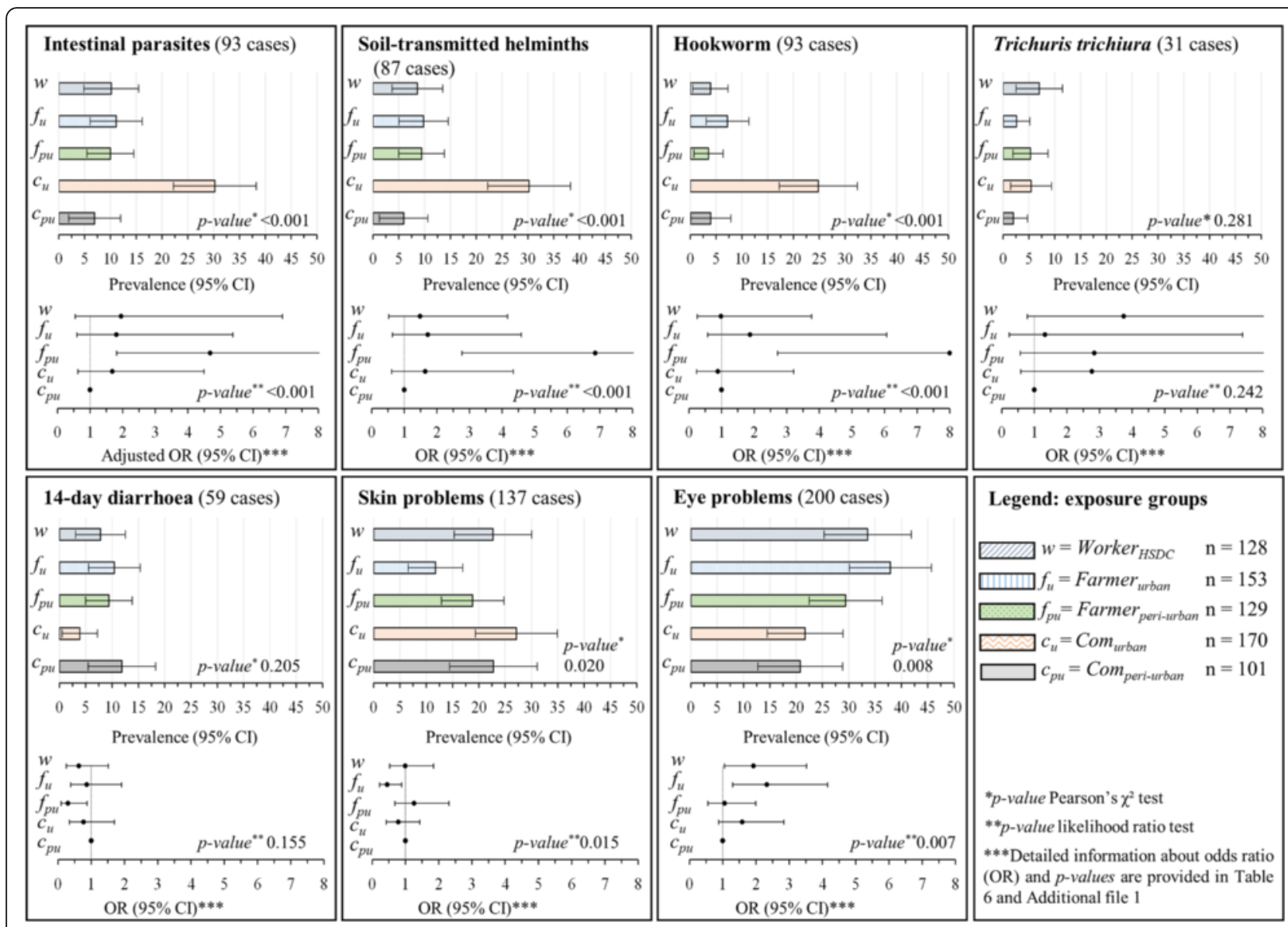

Fig. 3 Prevalence rates and adjusted odds ratios (OR) with $95 \%$ confidence intervals (Cls) for infection with any intestinal parasite, soiltransmitted helminth, hookworm, Trichuris trichiura and self-reported diarrhoea, skin problems and eye problems in a cross-sectional survey in the Than Tri district, Hanoi, between April and June 2014. Data for (i)"Comperi-urban" = people living in the peri-urban commune Duyen Ha 5 km away from the city along the Red River; (ii) "Com urban" = people living in the urban area of Hanoi, in Bang B village or Tam Hiep commune along the To

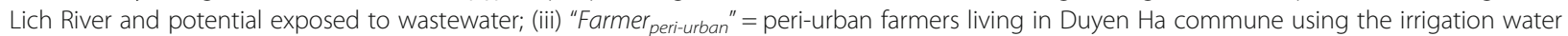
from Red River, wells or local drains, which are not contaminated with the city's wastewater; (iv) "Farmer urban" = urban farmers living in Bang B village or Tam Hiep commune reusing wastewater from To Lich River; and (v) "Worker HSDC" = workers from Hanoi Sewerage and Drainage Company (HSDC) maintaining drainage channels and operating the Yen So treatment plants

odds of intestinal parasite infection compared to other groups (aOR 5.3, 95 \% CI: 2.1-13.7). The considerable risk for intestinal parasite infection in this group might be explained, at least partially, by a reported lack of access to toilet facility at home and a general lack of awareness towards the health risk in regard to wastewater among peri-urban farmers. Moreover, it was striking that $72 \%$ of all participants reported to not having received deworming within the past 12 months before the study.

The observed differences between rural and peri-urban communities, especially in farmers, are in line with previous reports from studies in Asia and other parts of the world, indicating that urbanization is related to a decline of intestinal parasites $[1,6]$. We found that at least one third of the peri-urban inhabitants rely on bore hole water as source for drinking or bathing and that $15 \%$ of the peri-urban inhabitants had no access to toilet facilities at their home. Our findings support the conclusions of Do and colleagues who conducted a cross-sectional survey in Yen So commune in Hanoi in 2002 that revealed similar risk of intestinal parasite infections among urban farmers handling wastewater compared to periurban farmers [38]. However, prevalence rates of species-specific soil-transmitted helminths were considerably higher across all participants [A. lumbricoides (21.6\%), T. trichiura (9.8\%) and hookworm (21.8\%)] in [38], as compared to prevalences of $0.4 \%, 4.4 \%$ and $8.4 \%$, respectively, observed in our study. These considerably lower rates might suggest that the various improvements due to education and socioeconomic development in face of urbanization helped to bring down the prevalence of intestinal parasites over the last decade. Another reason is that people in many parts of 
Table 5 Self-reported health outcomes experienced in the last two weeks before the interview among the participants enrolled in a cross-sectional survey stratified by five exposure groups in the Than Tri district, Hanoi, between April and June 2014

\begin{tabular}{|c|c|c|c|c|c|c|c|c|c|c|c|}
\hline \multirow{3}{*}{$\begin{array}{l}\text { Self-reported health issues over the } \\
\text { past } 2 \text { weeks/ Exposure group }{ }^{\mathrm{a}}\end{array}$} & \multirow{2}{*}{\multicolumn{2}{|c|}{$\frac{\text { Com }_{\text {peri-urban }}}{N=101}$}} & \multirow{2}{*}{\multicolumn{2}{|c|}{$\begin{array}{l}C_{\text {urban }} \\
N=170 \\
\end{array}$}} & \multirow{2}{*}{\multicolumn{2}{|c|}{$\begin{array}{l}\text { Farmer }_{\text {peri-urban }} \\
N=129 \\
\end{array}$}} & \multirow{2}{*}{\multicolumn{2}{|c|}{$\begin{array}{l}\text { Farmer }_{\text {urban }} \\
N=153 \\
\end{array}$}} & \multirow{2}{*}{\multicolumn{2}{|c|}{$\begin{array}{l}\text { Worker }_{H S D C} \\
N=128\end{array}$}} & \multirow{3}{*}{$\begin{array}{l}\text { Chi-square } \\
\text { test } \\
P \text {-value }\end{array}$} \\
\hline & & & & & & & & & & & \\
\hline & $n$ & $\%$ & $n$ & $\%$ & $n$ & $\%$ & $n$ & $\%$ & $n$ & $\%$ & \\
\hline \multicolumn{12}{|l|}{ Diarrhoea } \\
\hline 14-day prevalence & 12 & 11.9 & 16 & 9.4 & 5 & 3.9 & 16 & 10.5 & 10 & 7.8 & 0.205 \\
\hline 7-day prevalence & 10 & 9.9 & 11 & 6.5 & 4 & 3.1 & 12 & 7.8 & 7 & 5.5 & 0.279 \\
\hline \multicolumn{12}{|l|}{ Number of episodes (14 days) } \\
\hline 1 & 9 & 8.9 & 12 & 7.1 & 5 & 3.9 & 12 & 7.8 & 6 & 4.7 & 0.411 \\
\hline 2 & 0 & 0.0 & 3 & 1.8 & 0 & 0.0 & 1 & 0.7 & 3 & 2.3 & \\
\hline 3 & 2 & 2.0 & 0 & 0.0 & 0 & 0.0 & 2 & 1.3 & 1 & 0.8 & \\
\hline 4 & 1 & 1.0 & 1 & 0.6 & 0 & 0.0 & 0 & 0.0 & 0 & 0.0 & \\
\hline Eye problems (one or more symptoms) & 21 & 20.8 & 50 & 29.4 & 28 & 21.7 & 58 & 37.9 & 43 & 33.6 & 0.008 \\
\hline Eye irritation & 8 & 7.9 & 6 & 3.5 & 10 & 7.7 & 23 & 15.0 & 32 & 25.0 & $<0.001$ \\
\hline Sensitivity to light & 2 & 2.0 & 1 & 0.6 & 0 & 0.0 & 5 & 3.3 & 3 & 2.3 & 0.172 \\
\hline Other eye problems & 11 & 10.9 & 45 & 26.4 & 18 & 14.0 & 41 & 26.8 & 13 & 10.2 & 0.352 \\
\hline Skin problems (one or more symptoms) & 23 & 22.8 & 32 & 18.8 & 35 & 27.1 & 18 & 11.8 & 29 & 22.7 & 0.024 \\
\hline Skin irritation & 3 & 3.0 & 5 & 2.9 & 6 & 4.7 & 2 & 1.3 & 13 & 10.2 & 0.004 \\
\hline Itching & 21 & 20.8 & 22 & 12.9 & 29 & 22.5 & 10 & 6.5 & 18 & 14.1 & 0.001 \\
\hline Other skin problems & 0 & 0.0 & 10 & 5.9 & 3 & 2.3 & 10 & 6.5 & 5 & 4.7 & 0.402 \\
\hline \multicolumn{12}{|l|}{ Other self-reported signs and symptoms } \\
\hline Headache & 38 & 37.6 & 69 & 40.6 & 68 & 52.7 & 84 & 54.9 & 50 & 39.1 & 0.006 \\
\hline Fever & 7 & 6.9 & 8 & 4.7 & 9 & 7.0 & 10 & 6.5 & 4 & 3.1 & 0.591 \\
\hline Abdominal pain & 27 & 26.7 & 40 & 23.5 & 39 & 30.2 & 42 & 27.5 & 26 & 20.3 & 0.398 \\
\hline Acute coughing & 25 & 24.8 & 46 & 27.1 & 39 & 30.2 & 44 & 28.8 & 40 & 31.3 & 0.822 \\
\hline Chronic coughing & 5 & 5.0 & 15 & 8.8 & 1 & 0.8 & 14 & 9.2 & 2 & 1.6 & 0.002 \\
\hline Chest pain & 13 & 12.9 & 30 & 17.6 & 23 & 17.8 & 30 & 19.6 & 18 & 14.1 & 0.582 \\
\hline Loss of weight & 14 & 13.9 & 16 & 9.4 & 14 & 10.9 & 17 & 11.1 & 5 & 3.9 & 0.113 \\
\hline Nausea & 12 & 11.9 & 16 & 9.4 & 7 & 5.4 & 15 & 9.8 & 5 & 3.9 & 0.125 \\
\hline Vomiting & 2 & 2.0 & 3 & 1.8 & 2 & 1.6 & 3 & 2.0 & 1 & 0.8 & 0.941 \\
\hline Vomiting of blood & 0 & 0.0 & 0 & 0.0 & 0 & 0.0 & 1 & 0.7 & 0 & 0.0 & 0.485 \\
\hline Muscle pain & 19 & 18.8 & 43 & 25.3 & 32 & 24.8 & 52 & 34.0 & 33 & 25.8 & 0.097 \\
\hline Back pain & 48 & 47.5 & 80 & 47.1 & 77 & 59.7 & 102 & 66.7 & 45 & 35.2 & $<0.001$ \\
\hline Joint pain & 30 & 29.7 & 74 & 43.5 & 68 & 52.7 & 91 & 59.5 & 29 & 22.7 & $<0.001$ \\
\hline Injuries & 3 & 3.0 & 8 & 4.7 & 5 & 3.9 & 8 & 5.2 & 5 & 3.9 & 0.922 \\
\hline
\end{tabular}

${ }^{a}$ Exposure groups: Com peri-urban: people living in the peri-urban commune Duyen Ha, $5 \mathrm{~km}$ away from the city along the Red River; Com ${ }_{u r b a n}$ : people living in the

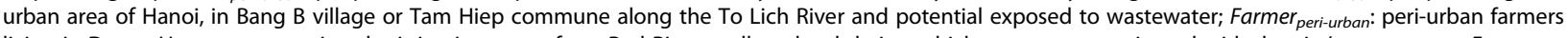
living in Duyen Ha commune using the irrigation water from Red River, wells or local drains, which are not contaminated with the city's wastewater; Farmer ${ }_{\text {urban: }}$ urban farmers living in Bang B village or Tam Hiep commune reusing wastewater from To Lich River; and Worker ${ }_{H S D C}$ : workers from Hanoi Sewerage and Drainage Company (HSDC) maintaining drainage channels and operating the Yen So treatment plants

Southeast Asia are being targeted by preventive chemotherapy against soil-transmitted helminthiasis and other neglected tropical diseases $[39,40]$. The low prevalence of A. lumbricoides and T. trichiura infections correlates with concentrations of $<1 \mathrm{egg} / \mathrm{l}$ found in the environment and the presumed low infection risk of $A$. lumbricoides and T. trichiura [29]. However, the absence of hookworm eggs does not correlate with the respective prevalence in the exposure groups, especially in peri-urban farmers [29]. This may be explained by the fact that only hookworm eggs in water were assessed, while larval stages and eggs in soil or sediments were not [41]. Another reason for hookworm transmission could be open defecation, which is mainly practised 
Table 6 Results of univariate and multivariate logistic regression analysis for total parasitic infections (Ascaris lumbricoides, Trichuris trichiura, hookworm and intestinal protozoa) in a cross-sectional survey in the Than Tri district, Hanoi, between April and June 2014

\begin{tabular}{|c|c|c|c|c|c|c|c|c|c|c|c|}
\hline \multirow{2}{*}{\multicolumn{2}{|c|}{$\begin{array}{l}\text { Intestinal parasitic infection }{ }^{\text {a }} \\
\text { (total population, } N=681 \text {; infections } 13.6 \%, n=93 \text { ) }\end{array}$}} & \multicolumn{2}{|c|}{ Infections } & \multicolumn{4}{|c|}{ Univariate logistic regression $^{c}$} & \multicolumn{4}{|c|}{ Multivariate logistic regression ${ }^{c}$} \\
\hline & & \multirow{2}{*}{$\begin{array}{l}n \\
101\end{array}$} & \multirow{2}{*}{$\frac{\%}{6.9}$} & \multirow{2}{*}{$\begin{array}{l}\mathrm{OR} \\
1.00\end{array}$} & \multicolumn{2}{|c|}{$95 \% \mathrm{Cl}$} & \multirow{2}{*}{$\frac{P \text {-value }}{<0.001}$} & \multirow{2}{*}{$\begin{array}{ll}\mathrm{aOR} \\
1.00\end{array}$} & \multicolumn{2}{|c|}{$95 \% \mathrm{Cl}$} & \multirow[t]{2}{*}{$P$-value ${ }^{d}$} \\
\hline Exposure group ${ }^{b}$ & Com $_{\text {peri-urban }}$ & & & & & & & & & & \\
\hline & $\mathrm{Com}_{\text {urban }}$ & 170 & 10.0 & 1.49 & 0.60 & 3.73 & 0.392 & 1.61 & 0.61 & 4.22 & 0.333 \\
\hline & Farmer $_{\text {peri-urban }}$ & 129 & 30.3 & 5.82 & 2.48 & 13.68 & $<0.001$ & 5.30 & 2.05 & 13.69 & 0.001 \\
\hline & Farmer urban $_{2}$ & 153 & 11.1 & 1.68 & 0.67 & 4.21 & 0.269 & 1.72 & 0.60 & 4.91 & 0.314 \\
\hline & Worker $_{H S D C}$ & 128 & 10.2 & 1.52 & 0.58 & 3.96 & 0.393 & 2.11 & 0.71 & 6.24 & 0.179 \\
\hline \multirow[t]{2}{*}{ Sex } & Male & 166 & 12.1 & 1.00 & & & & & & & \\
\hline & Female & 512 & 14.6 & 0.84 & 0.49 & 1.42 & 0.511 & 0.77 & 0.42 & 1.41 & 0.395 \\
\hline Age & & & & 1.02 & 1.01 & 1.04 & 0.001 & 1.01 & 1.00 & 1.03 & 0.122 \\
\hline \multirow[t]{5}{*}{ Educational attainment } & Never went to school & 15 & 20.0 & 1.00 & & & 0.035 & & & & \\
\hline & Primary school & 92 & 16.3 & 0.78 & 0.20 & 3.10 & 0.723 & 0.67 & 0.15 & 3.03 & 0.604 \\
\hline & Secondary school & 306 & 17.0 & 0.82 & 0.22 & 3.00 & 0.763 & 0.68 & 0.16 & 2.96 & 0.605 \\
\hline & Tertiary school & 205 & 8.8 & 0.39 & 0.10 & 1.49 & 0.167 & 0.33 & 0.07 & 1.62 & 0.173 \\
\hline & Higher education & 63 & 7.9 & 0.34 & 0.07 & 1.64 & 0.181 & 0.51 & 0.09 & 3.01 & 0.459 \\
\hline \multirow[t]{4}{*}{ Socioeconomic status } & Most poor & 155 & 18.6 & 1.00 & & & 0.114 & & & & \\
\hline & Poor & 178 & 11.8 & 0.61 & 0.33 & 1.12 & 0.110 & 0.89 & 0.44 & 1.82 & 0.754 \\
\hline & Less poor & 173 & 15.6 & 0.84 & 0.47 & 1.50 & 0.552 & 1.80 & 0.86 & 3.74 & 0.116 \\
\hline & Least poor & 175 & 9.7 & 0.49 & 0.26 & 0.93 & 0.030 & 1.07 & 0.48 & 2.39 & 0.868 \\
\hline Number of people per household & & & & 0.90 & 0.79 & 1.01 & 0.067 & 0.93 & 0.82 & 1.05 & 0.250 \\
\hline \multirow[t]{2}{*}{ Toilet facility at home } & Yes & 661 & 12.9 & 1.00 & & & & & & & \\
\hline & No & 20 & 40.0 & 5.14 & 2.10 & 12.57 & $<0.001$ & 3.12 & 0.88 & 11.03 & 0.078 \\
\hline \multirow[t]{2}{*}{ Toilet facility at work } & Yes & 458 & 12.1 & 1.00 & & & & & & & \\
\hline & No & 195 & 17.4 & 1.54 & 0.96 & 2.48 & 0.076 & 0.87 & 0.47 & 1.60 & 0.653 \\
\hline \multirow[t]{2}{*}{ Wastewater cause health issues } & No & 86 & 22.1 & 1.00 & & & & & & & \\
\hline & Yes & 595 & 12.4 & 0.50 & 0.28 & 0.88 & 0.016 & 0.74 & 0.39 & 1.40 & 0.352 \\
\hline \multirow[t]{2}{*}{ Flooding of living area } & No & 654 & 13.9 & 1.00 & & & & & & & \\
\hline & Yes & 27 & 7.4 & 0.49 & 0.12 & 2.13 & 0.344 & & & & \\
\hline \multirow[t]{2}{*}{ Flooding of working area } & No & 538 & 13.4 & 1.00 & & & & & & & \\
\hline & Yes & 143 & 14.7 & 1.11 & 0.66 & 1.88 & 0.687 & & & & \\
\hline \multirow[t]{2}{*}{ Drinking tap water } & No & 150 & 14.0 & 1.00 & & & & & & & \\
\hline & Yes & 531 & 13.6 & 0.96 & 0.57 & 1.63 & 0.890 & & & & \\
\hline \multirow[t]{2}{*}{ Drinking rain water } & No & 628 & 13.4 & 1.00 & & & & & & & \\
\hline & Yes & 53 & 17.0 & 1.32 & 0.62 & 2.81 & 0.464 & & & & \\
\hline \multirow[t]{2}{*}{ Drinking bore hole water } & No & 595 & 12.9 & 1.00 & & & & & & & \\
\hline & Yes & 86 & 18.6 & 1.54 & 0.85 & 2.78 & 0.155 & 0.91 & 0.41 & 2.01 & 0.808 \\
\hline Bathing with tap water & No & 90 & 16.7 & 1.00 & & & & & & & \\
\hline & Yes & 591 & 13.2 & 1.69 & 0.71 & 4.00 & 0.232 & & & & \\
\hline Bathing with rain water & No & 647 & 13.3 & 1.00 & & & & & & & \\
\hline & Yes & 34 & 20.6 & 1.31 & 0.80 & 2.13 & 0.278 & & & & \\
\hline Bathing with bore hole water & No & 514 & 12.8 & 1.00 & & & & & & & \\
\hline
\end{tabular}


Table 6 Results of univariate and multivariate logistic regression analysis for total parasitic infections (Ascaris lumbricoides, Trichuris trichiura, hookworm and intestinal protozoa) in a cross-sectional survey in the Than Tri district, Hanoi, between April and June 2014 (Continued)

\begin{tabular}{lllllllllllll}
\hline & Yes & 167 & 16.2 & 1.27 & 0.15 & 10.97 & 0.830 & & & & & \\
Preventive chemotherapy received in the past & $<6$ months & 69 & 7.2 & 1.00 & & & 0.038 & & & \\
& 6 to $<12$ months & 77 & 6.5 & 0.89 & 0.25 & 3.21 & 0.857 & 0.83 & 0.20 & 3.42 & 0.798 \\
& $<12$ months & 493 & 15.6 & 2.37 & 0.92 & 6.08 & 0.073 & 2.53 & 0.92 & 6.95 & 0.072 \\
& Never took deworming & 42 & 14.3 & 2.13 & 0.61 & 7.48 & 0.237 & 1.87 & 0.48 & 7.25 & 0.363 \\
\hline
\end{tabular}

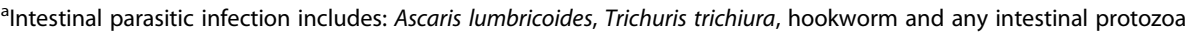

${ }^{b}$ Exposure groups: Com $_{\text {peri-urban: }}$ people living in the peri-urban commune Duyen Ha, $5 \mathrm{~km}$ away from the city along the Red River; Com urban: people living in the urban area of Hanoi, in Bang B village or Tam Hiep commune along the To Lich River and potential exposed to wastewater; Farmer ${ }_{\text {peri-urban: }}$ peri-urban farmers living in Duyen Ha commune using the irrigation water from Red River, wells or local drains, which are not contaminated with the city's wastewater; Farmer urban: urban farmers living in Bang B village or Tam Hiep commune reusing wastewater from To Lich River; and Worker ${ }_{H S D C}$ : workers from Hanoi Sewerage and Drainage Company (HSDC) maintaining drainage channels and operating the Yen So treatment plants

${ }^{c} P$-values were obtained from likelihood ratio tests. The core of the multivariate model included exposure group, sex, age, educational attainment, socioeconomic status and number of people per household. In addition, all risk factors with a $P$-value $<0.2$ in the univariate analyses were included into the multivariate regression analysis (as indicated in the table)

${ }^{\mathrm{d}} P$-values were obtained from likelihood ratio tests overall $P$-value of the respective categorical variable are indicated in italic letters

by peri-urban farmers, due to a lack of access to toilet facilities at home and at work [9]. Overall, the prevalence of intestinal protozoa detected in the current study $(<2 \%)$ was considerably lower than what has been reported from rural communities along Nhue River in Hanam province [11]. However, other intestinal protozoa species that were not detected by our diagnostic approach, such as Cryptosporidium spp. and Cyclospora spp., may be of importance [42]. The higher prevalence of diarrhoea, skin and eye diseases in farmers and workers exposed to wastewater compared to other groups is in line with reports from other studies conducted around Hanoi and along sanitation chains of urban and peri-urban settings [23, 24, 32]. Hence, further risk profiling such as quantitative microbial risk assessment (QMRA) or chemical risk assessments should be pursued for specific causative hazards (i.e. pathogenic bacteria, viruses and toxic chemicals, such as heavy metals, pesticides and fertilizers).

Our study has several limitations. First, the general attendance was lower than anticipated, and hence, we did not achieve the intended sample size. Results must be interpreted with caution. Secondly, most of the participants were females aged 40 years and above. Hence, our sample is not representative of the general population. However, it is representative for Hanoi's farmers as farming activities in urban and peri-urban communities are indeed mostly carried out by older women [43]. Thirdly, a single stool sample was examined, and hence, the point-prevalence rates of helminth and intestinal protozoa infections were underestimated [44]. In order to increase the sensitivity and to have a more precise understanding of the diversity of pathogenic organisms, multiple stool samples and a suite of highly sensitive diagnostic approaches such as polymerase chain reaction (PCR) or a metagenomics approach should be considered $[45,46]$. Fourthly, since this study only reflects one point in time, i.e. the rainy season, we may have missed seasonal outbreaks of typhoid, cholera and other diseases. More generally, there might be seasonal patterns of intestinal parasite infections, not captured by our study design [47-49]. Finally, it has been shown that self-reported disease outcomes (e.g. diarrhoea, skin and eye problems) are prone to reporting bias. Hence, longitudinal monitoring of diarrhoea incidence by well-trained health personnel are warranted to obtain a more accurate understanding [50].

Despite these limitations, our findings raise a number of important issues. First, even though the risk of parasite infection was relatively low, other pathogenic organisms such as viruses or bacteria may be transmitted directly or indirectly via the crops and fish produced with wastewater, which may give rise to diarrhoea, skin and eye diseases as reported by the participants of our study [16]. Secondly, even though we found low prevalence in adults, intestinal parasite infections may be a health issue in school-aged children in these settings, as children may play in agriculture fields or swim in ponds fed with wastewater. This is underlined by a study published in 2004, which detected a high prevalence rate in schoolchildren (77 \%), particularly T. trichiura (67\%) and A. lumbricoides (34\%), in the area around Hanoi [51]. Thirdly, integrated strategies to control or eliminate intestinal parasitic infections in such urban and peri-urban transition zones are needed [52, 53]. For example, adapted risk analysis frameworks and transmission assessment surveys of intestinal parasitic infections to break transmission cycles and approach local elimination of intestinal parasitic infections [54].

\section{Conclusions}

Taken together, our results suggest that peri-urban farmers are at higher risk of intestinal parasitic infections 
than their urban counterparts, even though exposure to highly contaminated wastewater is less common. Periurban communities, located only $5 \mathrm{~km}$ away from the urban area have limited access to improved sanitation and lack awareness towards health risks of exposure to contained water, which is associated with a high prevalence of intestinal parasitic infections. We recommend further quantitative risk assessments of microbial and chemical hazards and transmission assessment surveys of intestinal parasite infections, diarrhoeal, skin and eye diseases. Hence, there is a need for the implementation of control strategies to break transmission cycles, approach local elimination of parasitic infections and reduce risk for diarrhoea in urban and peri-urban transition zones in Hanoi and other cities in Southeast Asia.

\section{Additional file}

Additional file 1: Univariate logistic regression models for intestinal parasitic infections and self-reported signs. Table S1. Results of univariate logistic regression analysis for soil-transmitted helminth infections (Ascaris lumbricoides, Trichuris trichiura and hookworm) in a cross-sectional survey in the Than Tri district, Hanoi, between April and June 2014. Table S2. Results of univariate logistic regression analysis for Trichuris trichiura infections in a cross-sectional survey in the Than Tri district, Hanoi, between April and June 2014. Table S3. Results of univariate logistic regression analysis for hookworm infections in a cross-sectional survey in the Than Tri district, Hanoi, between April and June 2014. Table S4. Results of univariate logistic regression analysis for self-reported 14-days diarrhoea in a cross-sectional survey in the Than Tri district, Hanoi, between April and June 2014. Table S5. Results of univariate logistic regression analysis for self-reported skin problems in a cross-sectional survey in the Than Tri district, Hanoi, between April and June 2014. Table S6. Results of univariate logistic regression analysis for self-reported eye problems in a cross-sectional survey in the Than Tri district, Hanoi, between April and June 2014. (DOCX $106 \mathrm{~kb}$ )

\section{Acknowledgements}

Our special thanks go to all the study participants for actively participating in the survey. We thank our study team, namely: Nguyen Thanh Hien, Nguyen Duy Tien, Le Thi Huyen Trang and Pierre Schneeberger for all their efforts in data collection. Thanks are given to the staff of the Department of Parasitology at the National Institute of Malaria, Parasitology and Entomology (NIMPE), National Institute of Hygiene and Epidemiology (NIHE), National Institute of Veterinary Research (NIVR) who performed stool examinations. We also thank the staff of the health stations of Tam Hiep and Duyen $\mathrm{Ha}$ communes as well as community members and the workers and staffs of the Hanoi Sewerage and Drainage Company (HSDC) for their kind cooperation and participation in the study. We appreciate the institutional involvement of the Center for Public Health and Ecosystem Research (CENPHER), Hanoi School of Public Health. We are grateful to our project partners from the resource recovery and reuse project; namely, the International Water Management Institute (Colombo, Sri Lanka); the World Health Organization (Geneva, Switzerland); the International Centre for Water Management Services (Willisau, Switzerland); and the Department of Water and Sanitation in Developing Countries, Swiss Federal Institute of Aquatic Science and Technology (Dübendorf, Switzerland) for their valuable inputs. This study received financial support from the Swiss Agency for Development and Cooperation.

\section{Funding}

Funding was received from the Swiss Agency for Development and Cooperation (SDC).

\section{Authors' contributions}

All authors contributed to the study design. SF and PPD managed the study. SF and MSW drafted the manuscript. All authors contributed to redrafting the paper. All authors read and approved the final version of the manuscript.

\section{Competing interests}

The authors declare that they have no competing interests.

\section{Consent for publication}

Not applicable.

\section{Ethics approval and consent to participate}

The study protocol was approved by the institutional research commission of the Swiss Tropical and Public Health Institute (Swiss TPH; Basel, Switzerland; reference no. FK\#106). Ethical approval was obtained from the ethics committee of the cantons of Basel-Stadt and Basel-Landschaft (EKBB; reference no. 137/13) and the Hanoi School of Public Health (Hanoi, Vietnam; reference no. 010/2014/YTCC-HD3). This study is registered with the clinical trial registry ISRCTN (identifier: ISRCTN13601686).

All participants were informed about the purpose, procedures, and the potential risk and benefits of the study and they were invited to sign a written informed consent. Those with informed consent were assigned a unique identifier. In case of illiteracy, thumb-print and signature of a witness was requested. Results were communicated to participants and those found infected with soil-transmitted helminths were treated according to national guidelines with a single oral dose of albendazole $(400 \mathrm{mg}$ ). Participants found infected with intestinal protozoa were referred to a local health centre.

\section{Author details}

${ }^{1}$ Swiss Tropical and Public Health Institute, Basel, Switzerland. ${ }^{2}$ University of Basel, Basel, Switzerland. ${ }^{3}$ Center for Public Health and Ecosystem Research, Hanoi School of Public Health, Hanoi, Vietnam. ${ }^{4}$ Department of Parasitology, National Institute of Malaria, Parasitology, and Entomology, Hanoi, Vietnam.

Received: 4 December 2015 Accepted: 21 September 2016

Published online: 10 October 2016

\section{References}

1. Jex AR, Lim YAL, Bethony JM, Hotez PJ, Young ND, Gasser RB. Soiltransmitted helminths of humans in Southeast Asia: towards integrated control. Adv Parasitol. 2011;74:231-65.

2. Pham-Duc P, Nguyen-Viet H, Hattendorf J, Zinsstag J, Phung-Dac C, Zurbrügg C, et al. Ascaris lumbricoides and Trichuris trichiura infections associated with wastewater and human excreta use in agriculture in Vietnam. Parasitol Int. 2013;62:172-80.

3. Forrer A, Vounatsou P, Sayasone S, Vonghachack Y, Bouakhasith D, Utzinger $J$, et al. Risk profiling of hookworm infection and intensity in southern Lao People's Democratic Republic using Bayesian models. PLoS Negl Trop Dis. 2015;9:e0003486.

4. Karagiannis-Voules D-A, Odermatt P, Biedermann P, Khieu V, Schär F, Muth $\mathrm{S}$, et al. Geostatistical modelling of soil-transmitted helminth infection in Cambodia: do socioeconomic factors improve predictions? Acta Trop. 2015;141:204-12.

5. Utzinger J, Brattig NW, Leonardo L, Zhou X-N, Bergquist R. Progress in research, control and elimination of helminth infections in Asia. Acta Trop. 2015;141:135-45.

6. Utzinger J, Keiser J. Urbanization and tropical health: then and now. Ann Trop Med Parasitol. 2006;100:517-33.

7. Rydin Y, Bleahu A, Davies M, Dávila JD, Friel S, De Grandis G, et al. Shaping cities for health: complexity and the planning of urban environments in the 21st century. Lancet. 2012;379:2079-108.

8. Lai Y-S, Zhou X-N, Utzinger J, Vounatsou P. Bayesian geostatistical modelling of soil-transmitted helminth survey data in the People's Republic of China. Parasit Vectors. 2013;6:359.

9. Ziegelbauer K, Speich B, Mäusezahl D, Bos R, Keiser J, Utzinger J. Effect of sanitation on soil-transmitted helminth infection: systematic review and meta-analysis. PLoS Med. 2012;9:e1001162.

10. Schmidt W-P. The elusive effect of water and sanitation on the global burden of disease. Trop Med Int Health. 2014;19:522-7. 
11. Pham-Duc P, Nguyen-Viet H, Hattendorf J, Zinsstag J, Dac Cam P, Odermatt $P$. Risk factors for Entamoeba histolytica infection in an agricultural community in Hanam province, Vietnam. Parasit Vectors. 2011;4:102.

12. GSO. Multiple indicator cluster survey 2011. Hanoi: General Statistical Office Vietnam; 2011.

13. Do T, Mølbak K, Phung DC, Dalsgaard A. Helminth infections among people using wastewater and human excreta in peri-urban agriculture and aquaculture in Hanoi, Vietnam. Trop Med Int Health. 2007;12 Suppl 2:82-90.

14. Murray CJ, Vos T, Lozano R, Naghavi M, Flaxman AD, Michaud C, et al. Disability-adjusted life years (DALYs) for 291 diseases and injuries in 21 regions, 1990-2010: a systematic analysis for the Global Burden of Disease Study 2010. Lancet. 2012;380:2197-223.

15. Ingvertsen ST, Marcussen $\mathrm{H}$, Holm PE. Pollution and potential mobility of $\mathrm{Cd}, \mathrm{Ni}$ and $\mathrm{Pb}$ in the sediments of a wastewater-receiving river in Hanoi, Vietnam. Environ Monit Assess. 2013;185:9531-48.

16. $\mathrm{WHO}$. WHO guidelines for the safe use of wastewater, excreta and greywater. Volume I-IV. Geneva: World Health Organization; 2006.

17. Strande L, Ronteltap M, Brdjanovic D. Faecal sludge management: systems approach for implementation and operation. 1st ed. London: IWA Publishing; 2014

18. Bich TH, Quang LN, Ha LTT, Hanh TTD, Guha-Sapir D. Impacts of flood on health: epidemiologic evidence from Hanoi, Vietnam. Glob Health Action. 2011:4:6356.

19. Raschid-sally L, Jayakody P. Drivers and characteristics of wastewater agriculture in developing countries: results from a global assessment. Colombo: International Water Management Institute; 2008.

20. Drechsel P, Qadir M, Wichelns D. Wastewater: economic asset in an urbanizing world. London: Springer; 2015.

21. Do TT, Mølbak K, Cam PD, Dalsgaard A. Incidence of and risk factors for skin ailments among farmers working with wastewater-fed agriculture in Hanoi, Vietnam. Trans R Soc Trop Med Hyg. 2007;101:502-10.

22. Do TT, Bui TTH, Mølbak K, Phung DC, Dalsgaard A. Epidemiology and aetiology of diarrhoeal diseases in adults engaged in wastewater-fed agriculture and aquaculture in Hanoi, Vietnam. Trop Med Int Health. 2007;12 Suppl 2:23-33.

23. Hien BTT, Do TT, Scheutz F, Phung DC, Mølbak K, Dalsgaard A. Diarrhoeagenic Escherichia coli and other causes of childhood diarrhoea: a case-control study in children living in a wastewater-use area in Hanoi, Vietnam. J Med Microbiol. 2007;56:1086-96.

24. Anh VT, van der Hoek W, Ersbøll AK, Van TN, Tuan ND, Cam PD, et al. Dermatitis among farmers engaged in peri-urban aquatic food production in Hanoi, Vietnam. Trop Med Int Health. 2007;12 Suppl 2:59-65.

25. Nguyen TT, Dalsgaard A. Water used to moisten vegetables is a source of Escherichia coli and protozoan parasite contamination at markets in Hanoi, Vietnam. J Water Health. 2014;12:896-900.

26. Marcussen $\mathrm{H}, \mathrm{Ha}$ LTT, Polprasert $\mathrm{C}$, Holm PE. Contents and mass balances of cadmium and arsenic in a wastewater-fed fish pond of Hoang Mai, Hanoi, Vietnam. Environ Sci Health. 2012;47:2246-53.

27. Holm PE, Marcussen H, Dalsgaard A. Fate and risks of potentially toxic elements in wastewater-fed food production systems-the examples of Cambodia and Vietnam. Irrig Drain Syst. 2010;24:127-42.

28. Kuroda K, Nakada N, Hanamoto S, Inaba M, Katayama H, Do AT, et al. Pepper mild mottle virus as an indicator and a tracer of fecal pollution in water environments: comparative evaluation with wastewater-tracer pharmaceuticals in Hanoi, Vietnam. Sci Total Environ. 2015;506-507:287-98.

29. Fuhrimann S, Pham-Duc P, Tram NT, Hoang H, Dung DT, Ngoc P, et al. Microbial contamination and health risks due to wastewater use in urban farming in Hanoi, Vietnam. Sci Total Environ. 2016;566-567:1014-22.

30. WHO. Sanitation safety planning: manual for safe use and disposal of wastewater, greywater and excreta. Geneva: World Health Organization; 2015.

31. Lan A, Nguyen $H$, Nguyen $V$, Yamaji E. Wastewater reuse in Thanh Tri district, Hanoi suburb, Vietnam. Hanoi: Hanoi University of Civil Engineering; 2012.

32. Fuhrimann S, Winkler MS, Kabatereine NB, Tukahebwa EM, Halage AA,

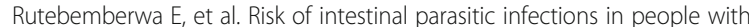
different exposures to wastewater and fecal sludge in Kampala, Uganda: a cross-sectional study. PLoS Negl Trop Dis. 2016;10:e0004469.
33. Katz N, Chaves A, Pellegrino J. A simple device for quantitative stool thick-smear technique in schistosomiasis mansoni. Rev Inst Med Trop São Paulo. 1972;14:397-400.

34. Utzinger J, Botero-Kleiven S, Castelli F, Chiodini PL, Edwards $\mathrm{H}_{\text {, }}$ Köhler N, et al. Microscopic diagnosis of sodium acetate-acetic acidformalin-fixed stool samples for helminths and intestinal protozoa: a comparison among European reference laboratories. Clin Microbiol Infect. 2010;16:267-73.

35. Filmer D, Pritchett LH. Estimating wealth effects without expenditure data or tears: an application to educational enrollments in states of India. Demography. 2001;38:115-32.

36. Strunz EC, Addiss DG, Stocks ME, Ogden S, Utzinger J, Freeman MC. Water, sanitation, hygiene, and soil-transmitted helminth infection: a systematic review and meta-analysis. PLoS Med. 2014;11:e1001620.

37. WHO. Helminth control in school-age children. Geneva: World Health Organization; 2011.

38. Do TT, van der Hoek W, Cam PD, Vinh KT, Van Hoa N, Dalsgaard A. Low risk for helminth infection in wastewater-fed rice cultivation in Vietnam. J Water Health. 2006:4:321-31

39. WHO. Soil-transmitted helminthiases: number of children treated in 2013. Wkly Epidemiol Rec. 2015;90:89-96.

40. WHO. Global programme to eliminate lymphatic filariasis: progress report, 2014. Wkly. Epidemiol. Rec. 2015;90:489-504

41. WHO. Integrated guide to sanitary parasitology. Geneva: World Health Organization; 2004.

42. Nguyen TT, Hoang LMN, Cam PD, Chung PT, Fyfe MW, Isaac-Renton JL, et al. Cyclospora spp. in herbs and water samples collected from markets and farms in Hanoi, Vietnam. Trop Med Int Health. 2008;13:1415-20.

43. Pham-Duc P, Nguyen-Viet H, Hattendorf J, Cam PD, Zurbrügg C, Zinsstag J, et al. Diarrhoeal diseases among adult population in an agricultural community Hanam province, Vietnam, with high wastewater and excreta re-use. BMC Public Health. 2014;14:978.

44. Knopp S, Mgeni AF, Khamis IS, Steinmann P, Stothard JR, Rollinson D, et al. Diagnosis of soil-transmitted helminths in the era of preventive chemotherapy: effect of multiple stool sampling and use of different diagnostic techniques. PLoS Negl Trop Dis. 2008;2:e331.

45. Becker SL, Vogt J, Knopp S, Panning M, Warhurst DC, Polman K, et al. Persistent digestive disorders in the tropics: causative infectious pathogens and reference diagnostic tests. BMC Infect Dis. 2013;13:1-21.

46. Schneeberger PHH, Becker SL, Pothier JF, Duffy B, N'Goran EK, Beuret C, et al. Metagenomic diagnostics for the simultaneous detection of multiple pathogens in human stool specimens from Côte d'Ivoire: a proof-ofconcept study. Infect Genet Evol. 2016;40:389-97.

47. Bwire G, Malimbo M, Maskery B, Kim YE, Mogasale V, Levin A. The burden of cholera in Uganda. PLoS Negl Trop Dis. 2013;7:e2545.

48. Mogasale V, Maskery B, Ochiai RL, Lee JS, Mogasale W, Ramani E, et al. Burden of typhoid fever in low-income and middle-income countries: a systematic, literature-based update with risk-factor adjustment. Lancet Glob Health. 2014;2:e570-80.

49. Neil KP, Sodha SV, Lukwago L, O-Tipo S, Mikoleit M, Simington SD, et al. A large outbreak of typhoid fever associated with a high rate of intestinal perforation in Kasese district, Uganda, 2008-2009. Clin Infect Dis. 2012:54:1091-9

50. Schmidt WP, Arnold BF, Boisson S, Genser B, Luby SP, Barreto ML, et al. Epidemiological methods in diarrhoea studies: an update. Int J Epidemiol. 2011:40:1678-92.

51. Uga S, Hoa NTV, Thuan LK, Noda S, Fujimaki Y. Intestinal parasitic infections in schoolchildren in a suburban area of Hanoi, Vietnam. Southeast Asian J Trop Med Public Health. 2005;36:1407-11.

52. WHO. Global strategic framework for integrated vector management. Geneva: World Health Organization; 2004.

53. Nguyen-Viet H, Zinsstag J, Schertenleib R, Zurbrügg C, Obrist B, Montangero A, et al. Improving environmental sanitation, health, and well-being: a conceptual framework for integral interventions. Ecohealth. 2009;6:180-91.

54. WHO. Assessing the epidemiology of soil-transmitted helmiths drunig a transmission assessment survey in the global programme for the elimination of lymphatic filariasis. Geneva: World Health Organization; 2015. 